University of Chitral

Journal of Botany |UOCHJB|
ISSN: 2616-9150

2017: Vol. 01:Issue No. 01: Page No.125-131

doi: https://doi.org/10.33195/uochib-v1i1382017

https://jb.uoch.edu.pk/index.php/j1

\title{
CARDIAC FUNCTION PROFILING AND ITS ANTIDIABETIC EFFECT OF DAPHNE MUCRONATA IN ALLOXAN INDUCED DIABETIC RABBITS
}

\author{
BASIT ALI*, RIZWANA BILQEES, AZIZULLAH \\ Department of Botany, University of Chitral, Pakistan
}

*Corresponding author: alibasitba05@gmail.com

Article Published on: 23 September 2019

\begin{abstract}
Diabetes mellitus is a chronic hyperglycemia associated with elevated plasma cholesterol. Natural and traditional herbal remedies are a source of new commercial products. Anti- diabetic potential of D. mucronata extracts (methanol) has been assessed in alloxan monohydrate diabetic induced rabbits. The extracts were given orally by 8 hours. The dose rate was $12 \mathrm{mg}, 125 \mathrm{mg}, 225 \mathrm{mg}$ and $325 \mathrm{mg} / \mathrm{kg}$ body weight respectively. At every 2 hours blood sample was collected, serum separated and glucose level was determined by kit method. The result suggests that the treatment of $325 \mathrm{mg} / \mathrm{kg}$ body weight significantly $(\mathrm{p}<0.05)$ decreased blood glucose and cholesterol level at $143 \mathrm{mg} / \mathrm{dl}$ and $166.33 \mathrm{mg} / \mathrm{dl}$ in the experimental group. Therefore, it is concluded that the $D$. mucronata possess significant anti-diabetic activity.
\end{abstract}

Keywords: Diabetic mellitus, D. mucronata alloxan monohydrate, glucose 


\section{Introduction}

Diabetes mellitus is one of the most commonplace persistent health troubles in the international. as presently available antidiabetic medicinal drugs have barriers in terms of safety, efficacy, and fee, it's miles an important studies location to investigate medicinal plant life for brand new antidiabetic compounds that could result in powerful, secure and less steeply-priced pharmacotherapy (Belayneh et al., 2019. Daphne mucronata royle is a plant belongs to the own family thymelaeaceae. leaves of this plant are toxic the plant possess insect repulsive abscesses for sore. the glue from leaves is used for muscular and nerve problems. plant poultice is carried out for rheumatism and sweeping. The roots and shoots of d. Mucronata royle are anthelmintic. these are utilized in treatment of gonorrhea. end result are used for ingesting purposes, to deal with eye troubles, to remedy skin. these are considered as treatment for face freckles, ticks, for killing lices and also are worried in coloring leather-based timber is used as firewood and utilized in practice of gun powder charcoal (Ashraf etal.,2018).the existing take a look at become executed to evaluate the antidiabetic and antidyslipidemic sports of methanolic extract of Daphne mucronata royle in experimental rabbits.

\section{Materials and methods}

\section{Selection of the plant:}

D. mucronata is present throughout the mountainous areas of Khyber Pakhtunkhwa.

\section{Collection of Plant:}

D. mucronata was collected from Village Golain District Chitral. The plant extract was prepared in methanol solvent.

\section{Selection of Animals for the experiment:}

The animal group Rabbits (Oryctolagus cuniculus) were selected for the conduction of this experiment upon them. 20 numbers of rabbits were purchased by the local supplier. Rabbits were divided in to five groups after induction of diabetes with Alloxan monohydrate beside the normal group. 


\section{Administration of Extract}

Group A was kept as untreated group.i.e control group.

Group B was treated with glucophage at the dose rate of $12 \mathrm{mg} / \mathrm{kg}$ body weight.

Group C was treated with plant extract of D. mucronata at dosage of $125 \mathrm{mg} / \mathrm{kg}$ body weight.

Group D was treated with D. mucronata extract at dosage $225 \mathrm{mg} / \mathrm{kg}$ body weight.

Group E was treated with $D$. mucronata extract at dosage $325 \mathrm{mg} / \mathrm{kg}$ body weight.

\section{Blood Sample Collection}

From the marginal veins at the back of ear, blood was obtained in Zero hours, Two hours, four hours, six hours and eight hours simultaneously and was analyzed through Double Beam UV Spectrophotometer.

\section{Results}

Group B was given Glucophage (Glibenclamide) for regular 8 hours at the interim of zero hrs, $2 \mathrm{hrs}$, $4 \mathrm{hrs}, 6 \mathrm{hrs}$ and $8 \mathrm{hrs}$. At the last of the process of treatment, the glucose and cholesterol level of Group B was recorded as $185 \mathrm{mg} / \mathrm{dl}$ and $167 \mathrm{mg} / \mathrm{dl}$ respectively.

Group C was kept on Daphne mucronata plant's extract at dosage of $125 \mathrm{mg} / \mathrm{dl}$ for continuous $8 \mathrm{hrs}$ at the interim of zero hrs, 2hrs, $4 \mathrm{hrs}$, $6 \mathrm{hrs}$ and $8 \mathrm{hrs}$. At the last of the process of treatment, the glucose and cholesterol level of Group C was recorded as 315 $\mathrm{mg} / \mathrm{dl}$ and $266 \mathrm{mg} / \mathrm{dl}$ respectively.

Group D was treated with plant extract of Daphne mucronata at dosage of 225 $\mathrm{mg} / \mathrm{kg}$ for continuous $8 \mathrm{hrs}$ at the interim of zero hrs, $2 \mathrm{hrs}$, $4 \mathrm{hrs}, 6 \mathrm{hrs}$ and $8 \mathrm{hrs}$. At the last of the process of treatment, the glucose level and cholesterol of Group D was recorded as $233 \mathrm{mg} / \mathrm{dl}$ and $258.66 \mathrm{mg} / \mathrm{dl}$ respectively.

Group E was treated with plant extract at the dose rate of $325 \mathrm{mg} / \mathrm{kg}$ for regular 8 hrs. It was given at the interval of zero hrs, $2 \mathrm{hrs}, 4 \mathrm{hrs}, 6 \mathrm{hrs}$ and $8 \mathrm{hrs}$. At the last of the process of treatment, the glucose and cholesterol level of Group E was recorded as 143 $\mathrm{mg} / \mathrm{dl}$ and $166.33 \mathrm{mg} / \mathrm{dl}$ respectively. 
Table 1: Blood glucose level $(\mathrm{mg} / \mathrm{kg})$ in alloxan induced diabetic rabbits.

\begin{tabular}{|c|c|c|c|c|c|}
\hline & $\begin{array}{l}\text { O hr } \\
\text { Reading }\end{array}$ & $\begin{array}{l}2 \mathrm{hr} \\
\text { Reading }\end{array}$ & $\begin{array}{l}4 \mathrm{hr} \\
\text { Reading }\end{array}$ & $\begin{array}{l}6 \mathrm{hr} \\
\text { Reading }\end{array}$ & $\begin{array}{l}8 \mathrm{hr} \\
\text { Reading }\end{array}$ \\
\hline Untreated Group & 89.66 & 96.33 & 95.33 & 92 & 95 \\
\hline $\begin{array}{l}\text { Diabetic Control + } \\
\text { Glibenclimide }(12 \mathrm{mg} / \mathrm{kg})\end{array}$ & 288 & 288.33 & 265 & 207.33 & 185.66 \\
\hline $\begin{array}{l}\text { Diabetic + Methanolic Extract } \\
(125 \mathrm{mg} / \mathrm{kg})\end{array}$ & 378 & 342.66 & 312.66 & 305.33 & 315 \\
\hline $\begin{array}{l}\text { Diabetic + Methanolic Extract } \\
(225 \mathrm{mg} / \mathrm{kg})\end{array}$ & 303.33 & 292 & 266.66 & 255 & 233.33 \\
\hline $\begin{array}{l}\text { Diabetic + Methanolic Extract } \\
(325 \mathrm{mg} / \mathrm{kg})\end{array}$ & 198.66 & 190.33 & 181 & 179.66 & 143 \\
\hline
\end{tabular}

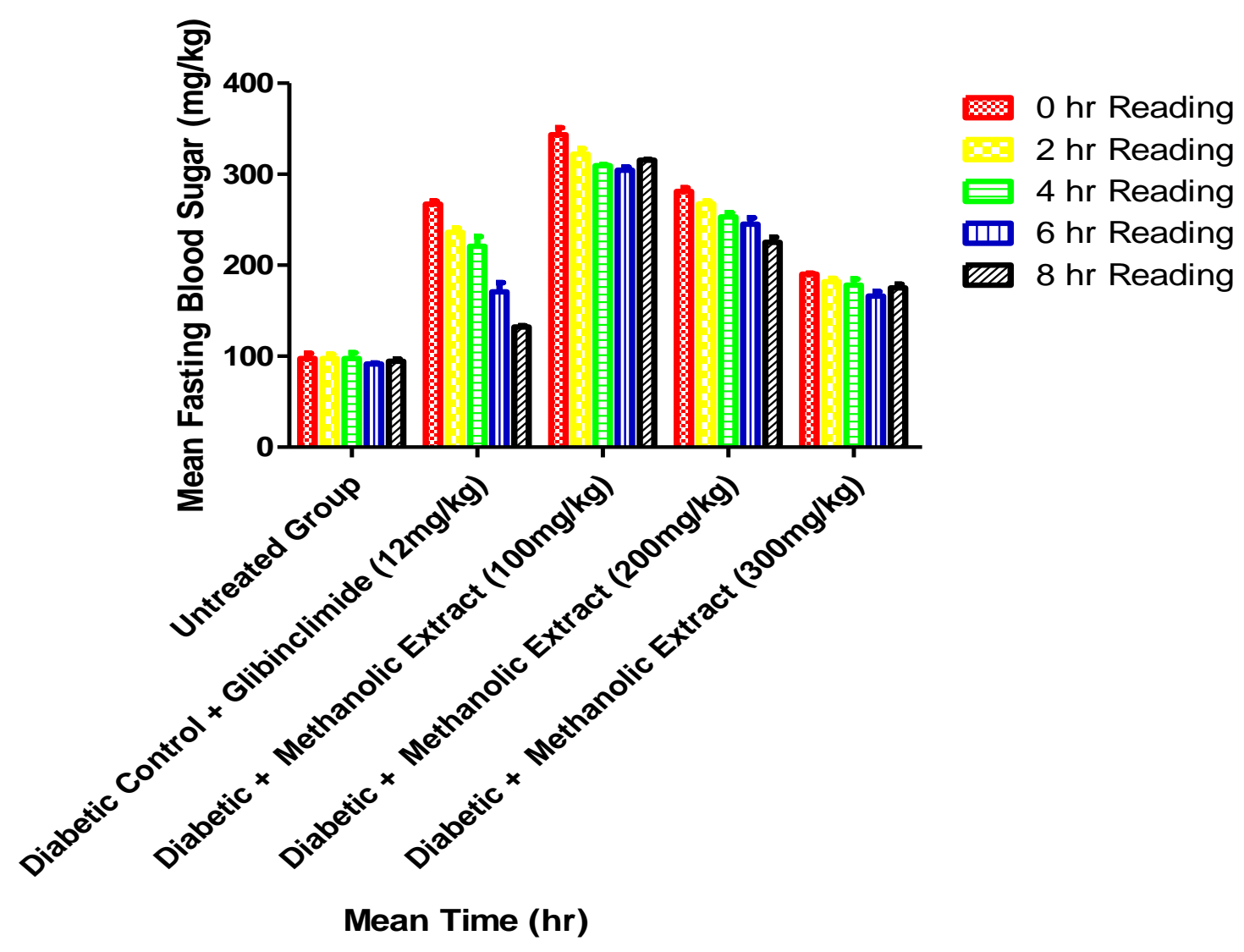

Figure-1.Blood glucose level of Rabbits 
Table 2: Blood cholesterol level (mg/kg) in alloxan induced diabetic rabbits.

\begin{tabular}{|c|c|c|c|c|c|}
\hline & $\begin{array}{l}0 \mathrm{hr} \\
\text { Reading }\end{array}$ & $\begin{array}{l}2 \mathrm{hr} \\
\text { Reading }\end{array}$ & $\begin{array}{l}4 \mathrm{hr} \\
\text { Reading }\end{array}$ & $\begin{array}{l}6 \mathrm{hr} \\
\text { Reading }\end{array}$ & $\begin{array}{l}8 \mathrm{hr} \\
\text { Reading }\end{array}$ \\
\hline Untreated Group & 103 & 102.66 & 103.66 & 105.66 & 102 \\
\hline $\begin{array}{l}\text { Diabetic Control + } \\
\text { Glibenclimide }(12 \mathrm{mg} / \mathrm{kg})\end{array}$ & 231 & 223.66 & 219.66 & 210.66 & 167 \\
\hline $\begin{array}{l}\text { Diabetic + Methanolic Extract } \\
(125 \mathrm{mg} / \mathrm{kg})\end{array}$ & 243.33 & 244.33 & 226.33 & 256.66 & 266 \\
\hline $\begin{array}{l}\text { Diabetic + Methanolic Extract } \\
(225 \mathrm{mg} / \mathrm{kg})\end{array}$ & 244.33 & 238 & 241.66 & 234 & 258.66 \\
\hline $\begin{array}{l}\text { Diabetic + Methanolic Extract } \\
(325 \mathrm{mg} / \mathrm{kg})\end{array}$ & 188.66 & 181.33 & 181 & 170 & 166.33 \\
\hline
\end{tabular}

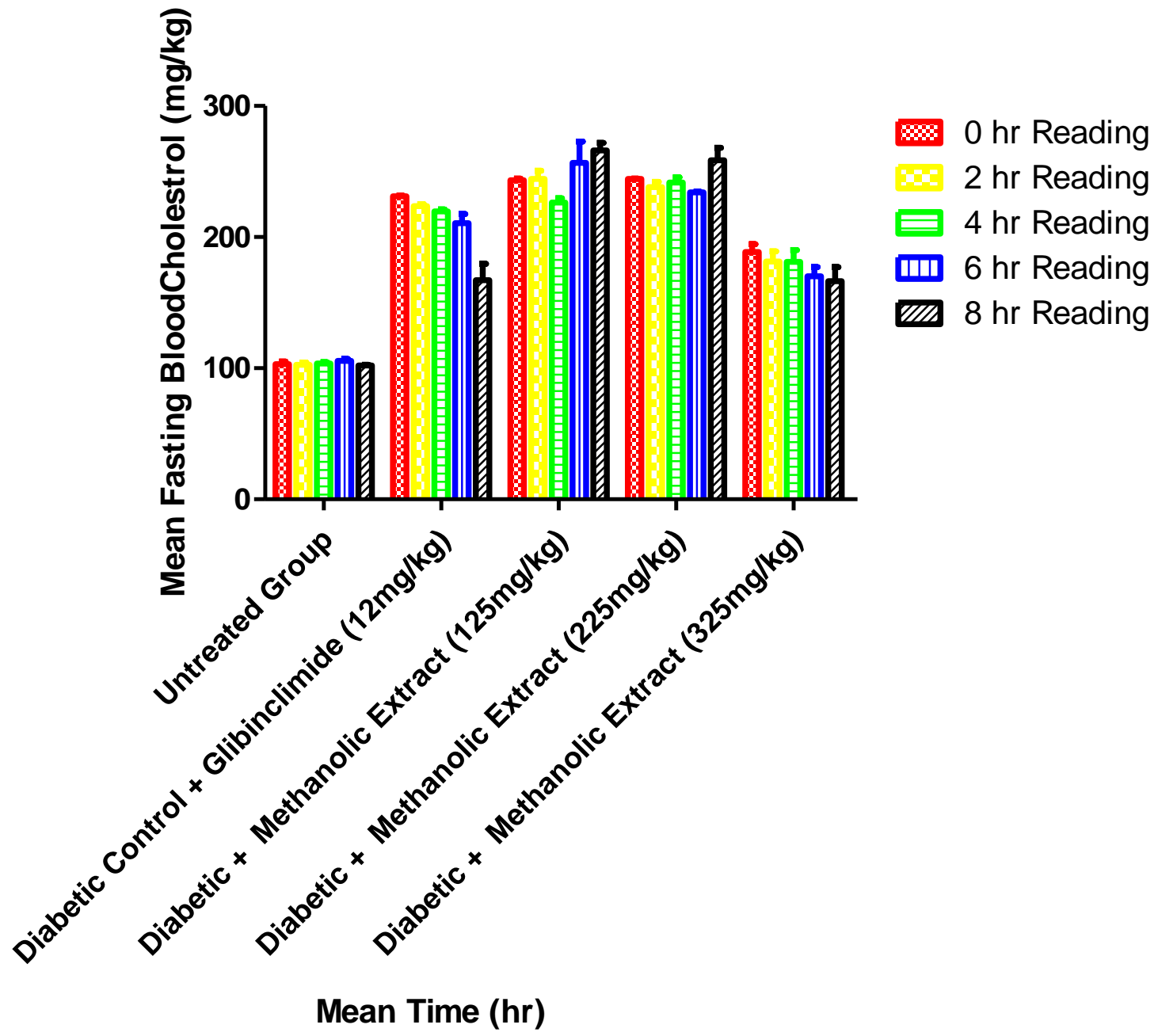

Figure-2. Blood cholesterol level of Rabbits

129 University of Chitral Journl of Botany |UOCHJB| 


\section{DISCUSSION}

Alloxan monohydrate induces diabetes mellitus in rabbits. In the process pancreas destroys and rabbits to have high glucose level in their blood, due to serum insulin level reduction. The present work reflects that there are some recreations of beta cells of pancreas which produce insulin. After three days of the application of the extract recipe. This generation rate reached to its high level and starting produce insulin apart from that the cholesterol level also have significant reduction in the Alloxan treated rabbits. There is also a phenomenon observed in these rabbits. There mobilization and high concentration of lipid serum level observed due to the freely mobilization of fatty acid from the peripheral fat source of secretion, maintenance of serum cholesterol level indicates in the extract that phytoestrogens and sapiens may exert their role in maintenance. The diabetes mellitus causes renal functions disturbance, resulting the urea high in concentration. This urea level also became down due to the treatment with the extract the rabbits. Side by side the main antioxidant uric acid in the blood is also reduces due to this disorder. The extract enhances antioxidant effect and normalizes the uric acid level. In the infected groups due to the occurrence of processes in different kinds as proteolysis, lipolysis and fluid loss causing the weight loss occur in the diabetic subjects. In such situations the extract works positively beneficial. The weight gained and body metabolism starts correctly after the extract's application. So, all the information and experiments reflected that this plant has significant and outstanding anti-diabetic and anti cholesterolomic activities.

The brought about of the seed extracts and watery extraction of plant named botani cally as Phyllanthus amarus at verbal dosage of 150,300 and $600 \mathrm{mg} / \mathrm{kg} \mathrm{b}$. wt. had inspect ed for its ant-diabetic and anti-lipidemic potentials. The dig up formed a dosage dependent lessen the serum cholesterol level, plasma glucose level and diminution in their weights of fasting treated mice. The domino effect conjure up that the extort might possibly be impro ving glucose peripheral operation of but the procedure on in what way this facility keep on indistinct (Adeneye et al., 2006)

\section{CONCLUSION}

Going to the conclusion, this experiment shows that the plant D. mucronata extracts retain significant anti-hypoglycemic and that of anti-hypocholestrolemic activities. 
It also has the property of antioxidant for oxidative strain generated by diabetes mellitus. In major of the suggestions the concerned optional plant may possess high qualitative affections when it collected from the hilly areas rather than that of plain areas for such kind of treatment purposes.

\section{Acknowledgement:}

We acknowledge Pharmacognosy Lab, University of Chitral, Khyber Pakhtunkhwa, Pakistan for the provision of space for this research.

\section{REFERENCES}

Belayneh, Y. M., Birru, E. M., \& Ambikar, D. (2019). Evaluation of hypoglycemic, antihyperglycemic and antihyperlipidemic activities of $80 \%$ methanolic seed extract of Calpurnia aurea (Ait.) Benth. (Fabaceae) in mice. Journal of Experimental Pharmacology, Volume 11, 73-83. doi:10.2147/jep.s212206

Ashraf, I., Zubair, M., Rizwan, K., Rasool, N., Jamil, M., Khan, S. A., ... Jaafar, H. Z. (2018). Chemical composition, antioxidant and antimicrobial potential of essential oils from different parts of Daphne mucronata Royle. Chemistry Central Journal, 12(1). doi:10.1186/s13065-018-0495-1

Adeneye, A., Amole, O., \& Adeneye, A. (2006). Hypoglycemic and hypocholesterolemic activities of the aqueous leaf and seed extract of Phyllanthus amarus in mice. Fitoterapia, 77(7-8), 511-514. doi:10.1016/j.fitote.2006.05.030 